\section{Prevalence of fungi associated with storage seeds of different maize varieties}

\author{
Ummay Sadia', Shamim Shamsi and Md. Abul Bashar² \\ Department of Botany, University of Dhaka, Dhaka-1000, Bangladesh
}

Bioresearch Communications

Volume 7, Issue 2, July 2021

DOI:

https://doi.org/10.3329/brc.v7i2.54376

\begin{abstract}
A total of seven species of fungi were isolated from seed samples of maize (Zea mays L.) collected from Bangladesh Agricultural Research Institute (BARI), Joydebpur, Gazipur. Association of fungi with maize seeds was recorded three times viz., within a month after harvest, after three and six months of storage at $25^{\circ} \mathrm{C}$ and $4^{\circ} \mathrm{C}$. The fungal association varied with duration of storage period. Seven fungi viz., Aspergillus flavus Link, A. fumigatus Fresenius, A. niger Van Teighem, Curvularia lunata (Wakker) Boedijn, Fsarium verticillioides, Penicillium italicum and Rhizopus stolonifer (Ehrenb.) Vuill., were isolated from the different maize varieties namely KhaiBhutta, Barnali, Mohor, Bari Misty Bhutta, BHM-3, BHM-5, BM-5, BHM-6, BHM-7, BM-7 and BHM-9. Species of Aspergillus, Penicillium and Rhizopus were predominating fung iwhich increased with the increase of storage period..
\end{abstract}

KEYWORDS: Fungi, Maize seed, Different varieties, Storage duration

RECEIVED: 16 March 2021, ACCEPTED: 07 June 2021

TYPE: Original Research
CORRESPONDING AUTHOR: Dr.ShamimShamsi, Department of Botany, University of Dhaka, Dhaka-1000, Bangladesh, Email:prof.shamsi@gmail.com

\section{Introduction}

Maize (Zea mays L.) belongs to the family Poaceae. It is a grass like plant with soft stem and its leaves are distichous with overlapping sheaths and relatively long broad leaves. It's height varies from $2-25^{\prime}$. The chromosome number is $2 \mathrm{n}=$ 20. The term maize was derived from South American Indian Arawak-Carib word (Mahiz). It is also called corn by the British and Americans ${ }^{1}$.

It is one of the most important cereal crops in the world and ranks third next to wheat and rice ${ }^{2}$.The US is ranked first in the world in corn production. Other top maize producing countries include China, Brazil, Mexico, Indonesia, India, France and Argentina ${ }^{3}$.

In 2019, maize yield for Bangladesh was 8.04 tons per ha. It grows well in Dhaka, Tangail, Dinajpur, Rangpur, Khagrachori, Chittagong and Mymensingh districts. In Bangladesh, it has a good potential as a cereal crop due to its low cost of production, wide adaptability and diversified use. Every year various kinds of diseases cause yield loss of maize. Maize suffers from 28 fungal diseases in seedling stage ${ }^{4}$. in which 11 are seed-borne ${ }^{5}$. Fungal infection is most widespread in stored grains and appears as mould on the affected ear or grains.

In Bangladesh farmers use hybrid seed imported from abroad under quarantine rules. Therefore, disease frequency is generally very low in the field of Bangladesh. But maize seeds are infected with different fungi in storage condition and causes heavy loss in both quality and quantity. Therefore, it imparts an adverse effect on poultry industry as well as human consumption. In Bangladesh very little information is available on storage diseases of maize grains and their management. Considering the importance of maize crop, the present research work was undertaken to find out the prevalence of fungi in the seeds of eleven selected maize varieties in different storage conditions.

\section{Materials and Methods}

The present study was carried out on the mycoflora of maize seeds in storage conditions. Seed Samples were collected from Bangladesh Agricultural Research Institute (BARI), Joydebpur, Gazipur during the tenure of 2011 to 2015. Eleven varieties of maize seeds viz. KhaiBhutta, Barnali, Mohor, Bari Misty Bhutta, BHM-3, BНM-5, ВНМ-6, ВНМ-7, ВНМ-9 BM-5, and BM-7 were collected (Plates 1-2). Collected seed samples were placed in clean brown paper bags and labeled it properly. All the samples were preserved at $4^{\circ} \mathrm{C}$ and $25^{\circ} \mathrm{C}$ in refrigerator and incubation chamber, respectively for subsequent use.

Isolation of fungi associated with maize seeds: 'Tissue planting' and 'Blotter' methods were used to isolate fungi from the collected maize seeds ${ }^{6-7}$.

Tissue planting method: The seeds were washed in sterile water and then surface sterilized by dipping in $10 \%$ Chlorox for3-4minutes. Then they were transferred into a sterile Petri plate containing sterile blotting paper to remove the surface water. The seeds were placed in Petri plates containing sterilized Potato Dextrose Agar (PDA) medium. Each Petri plate contained $15 \mathrm{ml}$ of PDA medium with an additionof 1 drop (ca. $0.03 \mathrm{ml}$ ) of lactic acid. A total of seventy seeds were transferred in 10 Petri plates. Then the inoculated plates were incubated at $25 \pm 2{ }^{\circ} \mathrm{C}$ for seven days. 
Blotter method: In this method, moist chamber was made by placing two layers of blotting paper on the bottom of a $9 \mathrm{~cm}$ diameter Petri plate, sufficient water was added to soak the blotting papers and then covered with upper plate. The moist chambers were sterilized within an autoclave at $121^{\circ} \mathrm{C}$ for 20 minutes. A total of 70 surface sterilized maize seeds were then transferred in 10 moist sterilized Petri plates. The inoculated moist chambers were incubated in an incubator at $25 \pm 2{ }^{\circ} \mathrm{C}$ for seven days. After incubation, the fungi associated with the seeds were recorded carefully.

The fungi growing out of the seeds were examined and identified whenever possible and transferred to PDA slants. The isolates were purified following dilution plate method (CAB 1968), then transferred on PDA slants and incubated at $25{ }^{\circ} \mathrm{C}$ for seven days in an incubator ${ }^{6}$. The culture slants were preserved at $10 \pm 0.5{ }^{\circ} \mathrm{C}$ in are Refrigerator for future studies in the Mycology and Plant Pathology Laboratory, Department of Botany, University of Dhaka, Bangladesh.

Fungal colonies grown out of the maize seeds were recorded on the $7^{\text {th }}$ day of incubation and continued for two weeks depending on the medium and the fungal organism associated with the seeds. Percentage frequency of occurrence of the fungal isolates was calculated by adopting the formula of Spurr and Welty $(1972)^{8}$.

Morphological studies: Morphological studies of the fungal isolates were done to determine their identity. For microscopic observations, fungal structures like mycelia, spore bearing structures and spores were scrapped off from the surface of the culture medium with a scalpel or blade or picked up with a needle and was mounted in lacto phenol over a clean slide. In case of hyaline structures, a little amount of anilene blue was added to the mounted fluid. A clean cover slip was placed over the material, excess fluid was removed by shaking with blotting paper and examined under microscope. The microscopic structural view of the fungi was taken by a digital camera. Identification of the isolates were determined following the standard literature ${ }^{9-14}$.

\section{Results and Discussion}

The percent mycoflora associated with eleven maize varieties at $4^{\circ} \mathrm{C}$ and $25^{\circ} \mathrm{C}$ temperatures at different storage months are presented in Tables $1 \& 2$. The fungi coming out of the incubated maize seeds are shown in Plates $1 \& 2$.

Association of fungi with maize seeds at $25^{\circ} \mathrm{C}$ temperature after one month of storage: Seven species of fungi belonging to five genera of Deuteromycetes were found to be associated with eleven varieties of maize seeds after one month of storage at $25^{\circ} \mathrm{C}$. The fungi were Aspergillus flavus Link, A. fumigates Fresenius, A. niger van Tieghem, Curvularia lunata (Wakker) Boedijn, Fusarium verticillioides (Sacc.) Nirenberg (=Fusarium moniliforme J. Sheld.), Penicillium italicum Wehmer, and Rhizopus stolonifer (Ehrenb.) Vuill.(Table 1). In the first month of storage at temperature $25^{\circ} \mathrm{C}$ frequency percentage of Aspergillus flavus was highest in KhaiBhutta (20) which was followed by Mohor, Barnali and BHM-3 (4) and BHM-6 (3). Frequency percentage of A. fumigatus was highest in KhaiBhutta and BM-7 (7) followed by BHM-3 (5), BHM-7 (4), and Bari Misty Bhutta (1). Frequency percentage of A. nigerwas highest in BHM-5 (42) followed by Bari MistiBhutta (23), Mohor (17), BHM-9 (11), BHM-6 (8) and Barnali (6) (Table 1).

Curvularia lunata was exclusively isolated from Mohor and frequency percentage of the fungus was 10 . The highest frequency percentage of $F$. verticillioides was found in BM-5 (12) which was followed by Barnali-7. The highest per cent frequency of $P$. italicum was found in BHM-9 (16) followed by BHM-5 (15) and BM-5 (12). The highest per cent frequency of $R$. stolonifer was found in Barnali (43) followed by BHM-7 (30), BM-7 (28), Bari Misty Bhutta and BHM-6 (20) and Mohor (19) (Table 1).

Association of fungi with maize seeds at $25^{\circ} \mathrm{C}$ temperature after 3 months of storage: After 3 months of storage at $25^{\circ} \mathrm{C}$ seven fungal species were isolated form different varieties of maize seeds. Frequency percentage of A. flavus, A. niger and $R$. stolonifer were much more than others. The frequency percentage of $A$. fumigates was highest in KhaiBhutta (11) which was followed byBM-7 (7), Bari Misty Bhutta and BHM-7 (4) BM-5 (2) and Barnali (1).The frequency percentage of A. nigerwas highest in BHM-9 (28) and lowest in Barnali (2). Frequency percentage of A. flavus was highest in Mohor (34) and lowest in BM-5 (2). Curvularia lunata was isolated from Mohor, frequency percentage of the fungus was 21 . The highest frequency percentage of $F$. verticillioides was found in Barnali (12) and lowest in Mohor (4). The highest per cent frequency of $P$. italicum was found in KhaiBhutta (20) followed by BHM-9 (16), BHM-5 (15) and BM-5 (12). The highest per cent frequency of $R$. stolonifer was found in BHM7 (36) followed by BM-7 (28), Bari Misty Bhutta (18), BHM6 (17), Mohor (14), BHM-9 (4) andKhaiBhutta (2) (Table 1).

Association of fungi with maize seeds at $25^{\circ} \mathrm{C}$ temperature after 6 months of storage: After six months of storage at $25^{\circ} \mathrm{C}$ it was observed that the frequency percentage of the species of Aspergillus spp., F.verticillioides, R. stolonifer and $P$. italicum was increased with the increase of storage period. Frequency percentage of $A$. flavus was highest in Mohor (95) which was followed by Bari Misty Bhutta (71), BHM-3 (66), BHM-5 (35) KhaiBhutta (28), Barnali (19), BHM-6 and BHM-7 (15). Frequency percentage of A. fumigatus was highest in BHM-6 (15) followed byBM-7 (7), KhaiBhutta, Mohor and BHM-7 (4) .Lowest count was recorded (1\%) Bari Misty Bhutta. Frequency percentage of A. niger was highest in BM-5 (50) followed by KhaiBhutta (38), BHM-5 (21), BHM7 (15), Bari MistiBhutta (14), BHM-9 (7), Barnali (6) and Mohor (4) (Table 1).

Curvularia lunata was exclusively isolated from Mohor and frequency percentage of the fungus was 35 . The highest frequency percentage of $F$. verticillioides was found in BHM6 (61) followed by BHM-5 (50), BHM-3 (14), BM-5 (12) and BHM-9 (2). The highest per cent frequency of P. italicum was found in Barnali (40) which was followed by Bari Misty Bhutta (24), BHM-9 (16), BM-5 (16) and KhaiBhutta (11). The highest percentage of $R$. stolonifer was found in BHM-7 (53) followed by Barnali (43), BHM-6 and BM-7 (20) and Mohor (19), Bari Misty Bhutta (14) and KhaiBhutta (8) (Table 1). 
Table 1.Frequency percentage of fungi with eleven varieties of maize seeds at $25^{\circ} \mathrm{Cduring}$ different storage months.

\begin{tabular}{|c|c|c|c|c|}
\hline $\begin{array}{l}\text { Maize } \\
\text { varieties }\end{array}$ & Fungi & $\%$ Frequency of & fungi at different & storage months \\
\hline & & 1 & 3 & 6 \\
\hline \multirow[t]{6}{*}{ KhaiBhutta } & Aspergillus flavus & 20 & 23 & 28 \\
\hline & A. fumigatus & 7 & 11 & 4 \\
\hline & A. niger & - & 12 & 38 \\
\hline & F. verticillioides & - & - & 4 \\
\hline & P. italicum & - & 20 & 11 \\
\hline & $R$. stolonifer & 7 & 2 & 8 \\
\hline \multirow{6}{*}{ Mohor } & Aspergillus flavus & 4 & 34 & 95 \\
\hline & A. fumigatus & - & - & 4 \\
\hline & A. niger & 17 & - & 4 \\
\hline & C. lunata & 10 & 21 & 35 \\
\hline & F. verticillioides & - & 4 & - \\
\hline & R. stolonifer & 19 & 14 & 19 \\
\hline \multirow{6}{*}{ Barnali } & Aspergillus flavus & 4 & 5 & 19 \\
\hline & A. fumigatus & - & 1 & - \\
\hline & A. niger & 6 & 2 & 6 \\
\hline & F. verticillioides & 7 & 12 & - \\
\hline & P. italicum & - & - & 40 \\
\hline & R. stolonifer & 43 & - & 43 \\
\hline \multirow{6}{*}{$\begin{array}{l}\text { Bari Misty } \\
\text { Bhutta }\end{array}$} & & & & \\
\hline & Aspergillus flavus & 1 & - & 71 \\
\hline & A. fumigatus & 23 & 4 & 1 \\
\hline & A. niger & - & 18 & 14 \\
\hline & P. italicum & 20 & - & 24 \\
\hline & R. stolonifer & - & 18 & 14 \\
\hline \multirow[t]{5}{*}{ BHM-3 } & Aspergillus flavus & 4 & 4 & 66 \\
\hline & A. fumigatus & 5 & - & - \\
\hline & A. niger & - & 2 & - \\
\hline & F. verticillioides & - & - & 14 \\
\hline & R. stolonifer & - & - & 14 \\
\hline \multirow[t]{5}{*}{ BHM-5 } & A. flavus & - & - & 35 \\
\hline & A. niger & 42 & 21 & 21 \\
\hline & C. lunata & - & - & 5 \\
\hline & F. verticillioides & - & - & 50 \\
\hline & P. italicum & 15 & 15 & - \\
\hline \multirow[t]{5}{*}{ BM-5 } & Aspergillus flavus & - & 2 & - \\
\hline & A. fumigatus & - & 2 & - \\
\hline & A. niger & 3 & - & 50 \\
\hline & F. verticillioides & 12 & - & 12 \\
\hline & P. italicum & 12 & 12 & 16 \\
\hline
\end{tabular}

Table 1 continued 


\begin{tabular}{|c|c|c|c|c|}
\hline \multirow{2}{*}{$\begin{array}{l}\text { Maize } \\
\text { varieties }\end{array}$} & Fungi & $\%$ Frequency of & fungi at different & storage months \\
\hline & & 1 & 3 & 6 \\
\hline \multirow[t]{5}{*}{ ВНM-6 } & Aspergillus flavus & 3 & 3 & - \\
\hline & A. fumigatus & - & - & 15 \\
\hline & A. niger & 8 & 20 & - \\
\hline & $F$. verticillioides & - & - & 61 \\
\hline & R. stolonifer & 20 & 17 & 20 \\
\hline \multirow[t]{4}{*}{ ВНM-7 } & Aspergillus flavus & - & - & 15 \\
\hline & A. fumigatus & 4 & 4 & 4 \\
\hline & A. niger & - & - & 15 \\
\hline & R. stolonifer & 30 & 36 & 53 \\
\hline \multirow[t]{2}{*}{ BM-7 } & A. fumigatus & 7 & 7 & 7 \\
\hline & R. stolonifer & 28 & 28 & 20 \\
\hline \multirow[t]{4}{*}{ ВНM-9 } & A. niger & 11 & 28 & 7 \\
\hline & F. verticillioides & - & - & 2 \\
\hline & P. italicum & 16 & 16 & 16 \\
\hline & $R$. stolonifer & - & 4 & - \\
\hline
\end{tabular}

represents no fungal growth

Association of fungi with maize seeds at $4^{\circ} \mathrm{C}$ after one month of storage: Six species of fungi viz., Aspergillus flavus, A. fumigatus, A. niger, F. verticillioides., P. italicum and $R$. stoloniferwere isolated from different varieties of maize seeds after one month of storage at $4{ }^{\circ} \mathrm{C}$. Frequency percentage of A. flavus was highest in BHM-3 (4) followed by BHM-6 (3), KhaiBhutta (2) and Barnali (1).Similarly frequency percentage of $A$. fumigatus was highest in KhaiBhutta and BM-7 (7) followed by BHM-3 (5), BHM-7 (4) and Bari Misty Bhutta (1). Frequency percentage of A. niger was highest in Mohor (20) followed by Barnali (3), Bari MistiBhutta and BHM-9 (2) (Table 2).

$F$. verticillioides was exclusively isolated from Bari Misty Bhutta. The highest per cent frequency of $P$. italicum was found in BHM-9 (16) which was followed by BHM-5 (15) and BM-5 (12). The highest per cent frequency of $R$. stolonifer was found in Barnali 12 followed by KhaiBhutta (8) (Table 2). Association of fungi with maize seeds at $4^{\circ} \mathrm{C}$ temperature after 3 months of storage: Aspergillus flavus, A. fumigatus, A. niger, Curvularia lunata, $F$. verticillioides, $P$. italicum $\operatorname{nd} R$. Stolonifer were isolated after 3 months of storage at $4^{\circ} \mathrm{C}$. Frequency percentage of $A$. flavus was highest in Mohor, Barnali and BHM-3 (4) followed by BHM-6 (3). Frequency percentage of $A$. fumigatus was highest in KhaiBhutta and BM-7 (7) followed by BHM-3 (5), Bari Misty BHM-7 (4) and Bari Misty Bhutta (1). Frequency percentage of $A$. niger was highest in Bari Misty Bhutta (32) followed by BHM-9 (28), BM-5 (22), Mohor (21), BHM-3 (20), BHM-5 (12) and Barnali (6) (Table 2).
Curvularia lunata was exclusively isolated from Mohor. Frequency percentage of the fungus was 11 . The highest frequency percentage of $F$. verticillioides was found in BM-5 (17). The highest per cent frequency of $P$. italicum was found in BHM-9 (20) which was followed by BM-5 (17) and BHM5 (8). The highest per cent frequency of $R$. stolonifer was found in Barnali (43) which was followed by Bari Misty Bhutta and BHM-6 (20), Mohor (19), BM-7 (12), KhaiBhutta (7) and BHM-7 (3) (Table 2).

Association of fungi with maize seeds at $4^{\circ} \mathrm{C}$ after 6 months of storage: Except $C$. lunata all the six species of fungi found in the Ist and 3rd month of storage were isolated from eleven varieties of maize seeds. Frequency percentage of A. flavus was highest in Mohor (20) which was followed by Barnali (12), KhaiBhutta and BHM-3 (4) and BHM-6 (3). Frequency percentage of $A$. fumigatus was highest in Bari Misty Bhutta (12) followed by BM-7 (7). Barnali (6) and BHM-3 (5). Frequency percentage of $A$. niger was highest in BHM-5 and BM-5 (50) which was followed by BHM-3 (32), BHM-9 (28), Bari MistiBhutta (23), Mohor (21). BHM-6 (20) and Barnali (6) (Table 2).

The highest per cent frequency of $F$. verticillioides was found in Barnali (32) which was followed by BM-5 (12), Mohor (5) and KhaiBhutta (4). The highest per cent frequency of $P$. italicumwas found in BHM-9 (16) followed by BHM-5 (15) and BM-5 (12). The highest percentage of $R$. stolonifer was found in Barnali (50) followed by BHM-7 (30), BM-7 (28), Bari Misty Bhutta and BHM-6 (20), Mohor (19) and KhaiBhutta (10) (Table 2). 
Table 2.Frequency percentage of fungi with eleven varieties of maize seeds at $4{ }^{\circ} \mathrm{C}$ during different months of storage.

\begin{tabular}{|c|c|c|c|c|}
\hline $\begin{array}{l}\text { Maize } \\
\text { varieties }\end{array}$ & Fungi & \% Frequency of & fungi at different & storage months \\
\hline & & 1 & 3 & 6 \\
\hline \multirow[t]{4}{*}{ KhaiBhutta } & Aspergillus flavus & 2 & - & 4 \\
\hline & A. fumigatus & 7 & 7 & 1 \\
\hline & F. verticillioides & - & - & 4 \\
\hline & Rhizopus. stolonifer & 8 & 7 & 10 \\
\hline \multirow[t]{5}{*}{ Mohor } & Aspergillus flavus & - & 4 & 20 \\
\hline & A. niger & 20 & 21 & 21 \\
\hline & C. lunata & - & 11 & - \\
\hline & F. verticillioides & - & - & 5 \\
\hline & R. stolonifer & - & 19 & 19 \\
\hline \multirow[t]{6}{*}{ Barnali } & Aspergillus flavus & 1 & 4 & 12 \\
\hline & A. fumigatus & - & - & 6 \\
\hline & & 1 & 3 & 6 \\
\hline & A. niger & 3 & 6 & 6 \\
\hline & F. verticillioides & - & 4 & 32 \\
\hline & $R$. stolonifer & 12 & 43 & 50 \\
\hline \multirow{5}{*}{$\begin{array}{l}\text { Bari Misty } \\
\text { Bhutta }\end{array}$} & & & & \\
\hline & A. fumigatus & 1 & 1 & 12 \\
\hline & A. niger & 2 & 32 & 23 \\
\hline & F. verticillioides & 2 & - & - \\
\hline & R. stolonifer & - & 20 & 20 \\
\hline \multirow[t]{3}{*}{ BHM-3 } & Aspergillus flavus & 4 & 4 & 4 \\
\hline & A. fumigatus & 5 & 5 & 5 \\
\hline & A. niger & - & 20 & 32 \\
\hline \multirow[t]{2}{*}{ BHM-5 } & A. niger & - & 12 & 50 \\
\hline & P. italicum & 15 & 8 & 15 \\
\hline \multirow[t]{3}{*}{ BM-5 } & A. niger & - & 22 & 50 \\
\hline & F. verticillioides & - & 12 & 12 \\
\hline & P. italicum & 12 & 17 & 12 \\
\hline \multirow[t]{3}{*}{ ВНM-6 } & Aspergillus flavus & 3 & 3 & 3 \\
\hline & A. niger & - & - & 20 \\
\hline & R. stolonifer & - & 20 & 20 \\
\hline \multirow[t]{2}{*}{ BHМ-7 } & A. fumigatus & 4 & 4 & - \\
\hline & R. stolonifer & - & 3 & 30 \\
\hline \multirow[t]{2}{*}{ BM-7 } & A. fumigatus & 7 & 7 & 7 \\
\hline & R. stolonifer & - & 12 & 28 \\
\hline \multirow[t]{2}{*}{ ВНМ-9 } & A. niger & 2 & 28 & 28 \\
\hline & P. italicum & 16 & 20 & 16 \\
\hline
\end{tabular}

- represents no fungal growth 
Akonda et al. (2016) collected maize seed samples from Bogra, Gaibandha, Rangpur and Mymensingh of Bangladesh and reported nine species of fungi namely Aspergillusf lavus, A. niger, Alternaria alternata, Bipolaris maydis, Curvularia lunata, Fusarium oxysporum, F. moniliforme, Penicillium oixalicum and Rhizopus stolonifer ${ }^{15}$. Deepavali and Nilima (2013) isolated eight fungal species from maize seeds. Frequency occurrence of $A$. niger and A. flavus was very high in all varieties of maize ${ }^{16}$. The difference of fungal species associated with maize varieties may be due to difference of maize varieties, location of study area and storage temperature.

The fungal genera typically found in stored grains were Aspergillus, Penicillium, Fusarium and some xerophilic species, several of them with capabilities of producing toxins (Christensen 1987 and Lacey 1989) ${ }^{17-18}$.

Arinze and Sokirko (1986), Sitara and Akhtar (2007) recorded that major maize seed storage mycoflora include Aspergillus flavus, A. niger, Fusarium moniliforme, Helminthosporium sp., Alternaria sp., Rhizopus sp. and Penicillium sp. ${ }^{19-20}$.

Fusarium moniliforme commonly occurs in maize seed, where it has variable effects on seed germination and seedling health causing seedling diseases, root rot, stalk rot and ear or kernel rot (Bacon and Hinton 1996. Kaspars et al. (2016) found the fungi from Alternaria, Fusarium and Penicillium spp. were most frequently isolated from maize grain Binyam and Girma (2016) found Aspergillus spp. were the most dominant storage fungi followed by Fusarium spp. with maize seeds in different storage ${ }^{21-23}$.

\section{Conclusions}

The farmer preserved seed and certified maize seed is highly infested with a number of fungal seed borne pathogens and this can affect germination capacity of the seed. Seed selection is useful in improving seed germination and reducing the seed borne spectrum of most pathogens of maize. Ihe Aspregilus spp. are the most dominant storage fungi followed by $R$. stolonifer were isolated in this study. These fungi are important in producing secondary metabolites which are carcinogenic to both humans and animals. Since these storage fungi are very important in causing postharvest yield losses and production of Mycotoxins, accurate detections and identifications are crucial in order to develop an appropriate management strategies. In Bangladesh there is a great gap of experiments on stored maize pathogens. So, giving attentions to these pathogens may play a vital role in our country's development and transformation strategy. Findings of the present investigation will be helpful for designing proper management of maize seed.

\section{Acknowledgement}

The first author gratefully acknowledges to the University of Dhaka for providing financial support in her research through "M. Phil Scholarship".

\section{References}

1. Onuegbu, B.A. and Oji-Isoma, J. 2000. Effect of commercial bleach on seedling damping-off of pepper caused by Sclerotium rolfsii Sacc. Scientia Africa 1(1): 44-47.
2. Aldrich, S.R., Scott, W.O. and Leng, E.R. 1975.Modern corn production. $2^{\text {nd }}$ edition. United States of America. pp. 1-5.

3. FAO 2005. Food and Agriculture Organization, Agriculture Outlook: Food and Agricultural organization of the United Nations.

4. Bari, M.A. and Alam M.S. 2004. Major diseases of wheat and maize and their control. Abengali booklet published from the Division of Plant Pathology, BARI, Joydebpur, Gazipur. 2: 12-16.

5. Fakir, G.A. 2001. List of seed borne diseases of important crops occurring in Bangladesh. Seed Pathol. Lab., Dept. Pl. Pathol., Bangladesh Agricultural University, Mymensingh. p. 9

6. CAB (Commonwealth Agricultural Bureau) 1968. Plant Pathologist's Pocket Book. $1^{\text {st }}$ edition. The Commonwealth Mycological Institute, England. pp. 267.

7. Anonymous. 2014. International Rules for Seed Testing .International Seed Testing Association, Switzerland, pp. 10.

8. Spurr, H.W. and Welty, R.E. 1972. Incidence of tobacco leaf mycoflora in relation to brown spot disease and fungicidal treatment. Phytopathology. 62: 916-920.

9. Barnett, H.L. and Hunter B.B. 2000. Illustrated genera of imperfect fungi. Fourth edition. Pub. Co. The American Phytopathological society, St. Paul, Minnesota. pp.185.

10. Booth, C. 1971. The Genus Fusarium. The Commonwealth Mycological Institute, Kew, England. pp. 221.

11. Ellis, M.B. 1971. Dematiaceous Hyphomycetes. The Commonwealth Mycological Institute, England, pp. 608.

12. Ellis, M.B. 1976. More Dematiaceous Hyphomycetes. The Commonwealth Mycological Institute, England, pp. 507.

13. Raper, K. B. and Thom, C. and. Fennel. L.1949. A Manual of the Penicillium. The Willium and Wilkins. Company, Baltimore, U. S. A. pp.875.

14. Thom, C.andRaper, K.B. 1945. A Manual of the Aspergilli. The Williams \& Wilkins Company. Baltimore. pp. 373.

15. Akonda Md., Yasmin, M. and Hossain. 2016. Incidence of seed born emyco flora and their effects on germination of maize seeds. Int. Journal of Agro. and Agric. Res. (IJAAR). 8 (1): 87-92.

16. Deepavali, S and Nilima, W. 2013. Incidence seed borne mycoflora on maize and its effects on seed germination. L. nternational Journal of Current Research 5(12):4151-4155.

17. Christensen, C.M. 1987. Field and storage fungi. In: Beuchat LR (Ed), Food and Beverage Mycology. New York, Van Nostrand Reinhold. pp. 211-232.

18. Lacey, J. 1989. Pre- and post-harvest ecology of fungi causing spoilage of foods and other stored products. Journal of Applied Bacteriology Symposium Supplement. pp. 11-25.

19. Arinze, O.J. and Sokirko, V.P. 1986. Physiological and biochemicals changes in maize seedlings obtained from seeds infected by mould fungi. Selskokhoz Yaistyennaya Bio No. 8: 83-85. Rev. Pl. Path. 65(12): 5989. 
20. Sitara, U. and Akhtar, S. 2007. Efficacy of fungicides, sodium hypochlorite and neem seed powder to control seed borne pathogens of maize. Pak. J. Bot. 39(1): 285292.

21. Bacon, C.W. and D.M. Hinton 1996. Symptomless endophytic colonization of maize by Fusarium moniliforme. Can. J. Bot. 74:1195-1202.
22. KasparsGulbis, BirutaBankina, GunitaBimsteina, IngridaNeusa-Luca, AnceRoga, Davis Fridmanis 2016. Fungal diversity of maize (Zea mays L.) grain.Rural sustainability Research. 35 (330).

23. Binyam, T. and Girma, A. 2016. Detection of fungi infecting maize (Zea mays L.) seeds in different storages around Jimma, Southwestern Ethiopia. Journal of Plant Pathology \& Microbiology 7:3. 

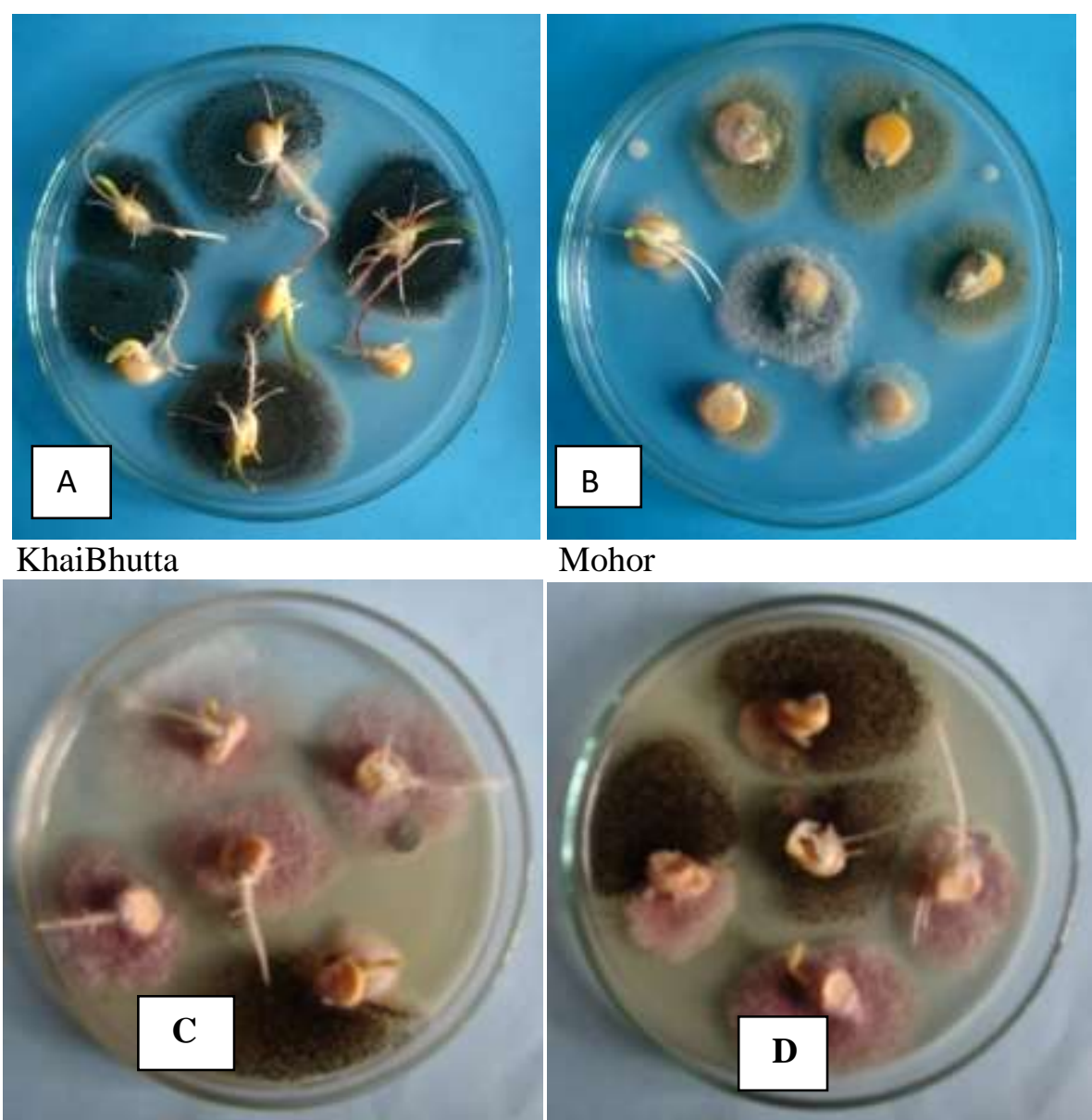

Mohor

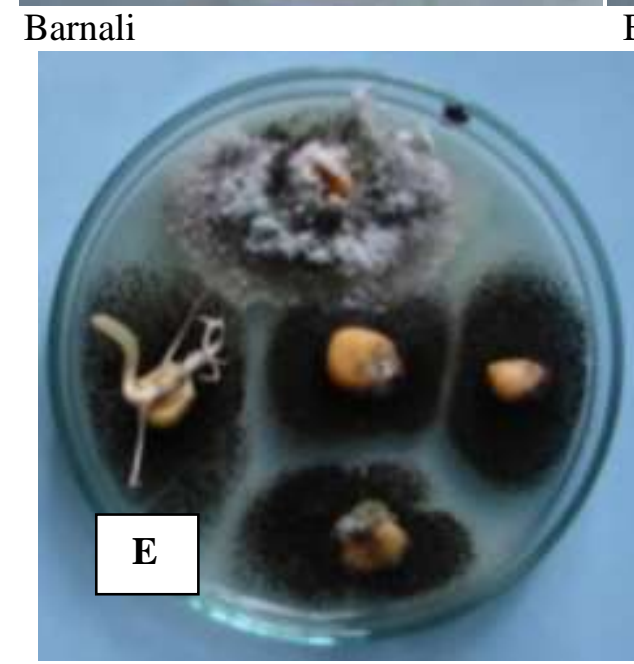

BHM-3

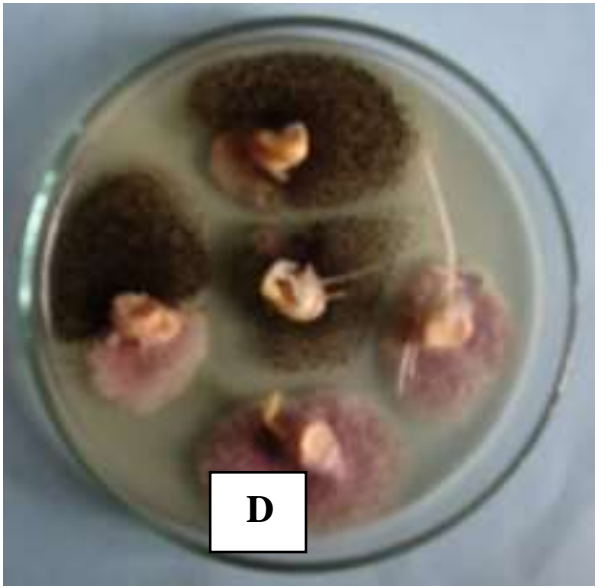

Bari Misty Bhutta

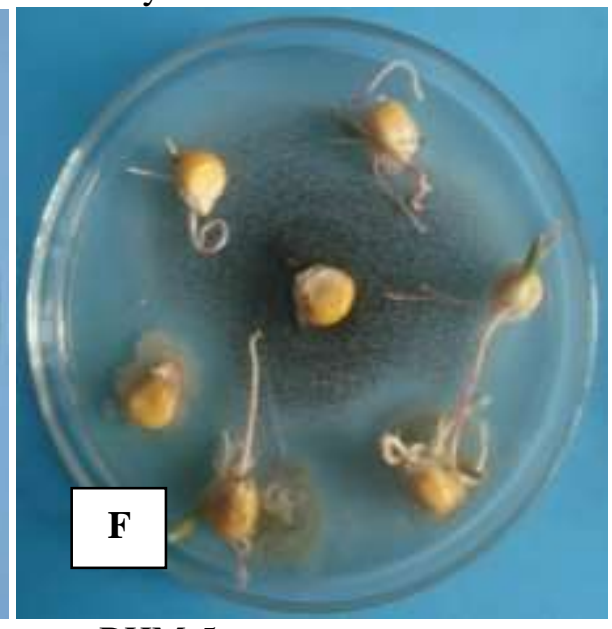

BHM-5

Plate 1. A-F: Fungi associated with different varieties of maize seeds. 

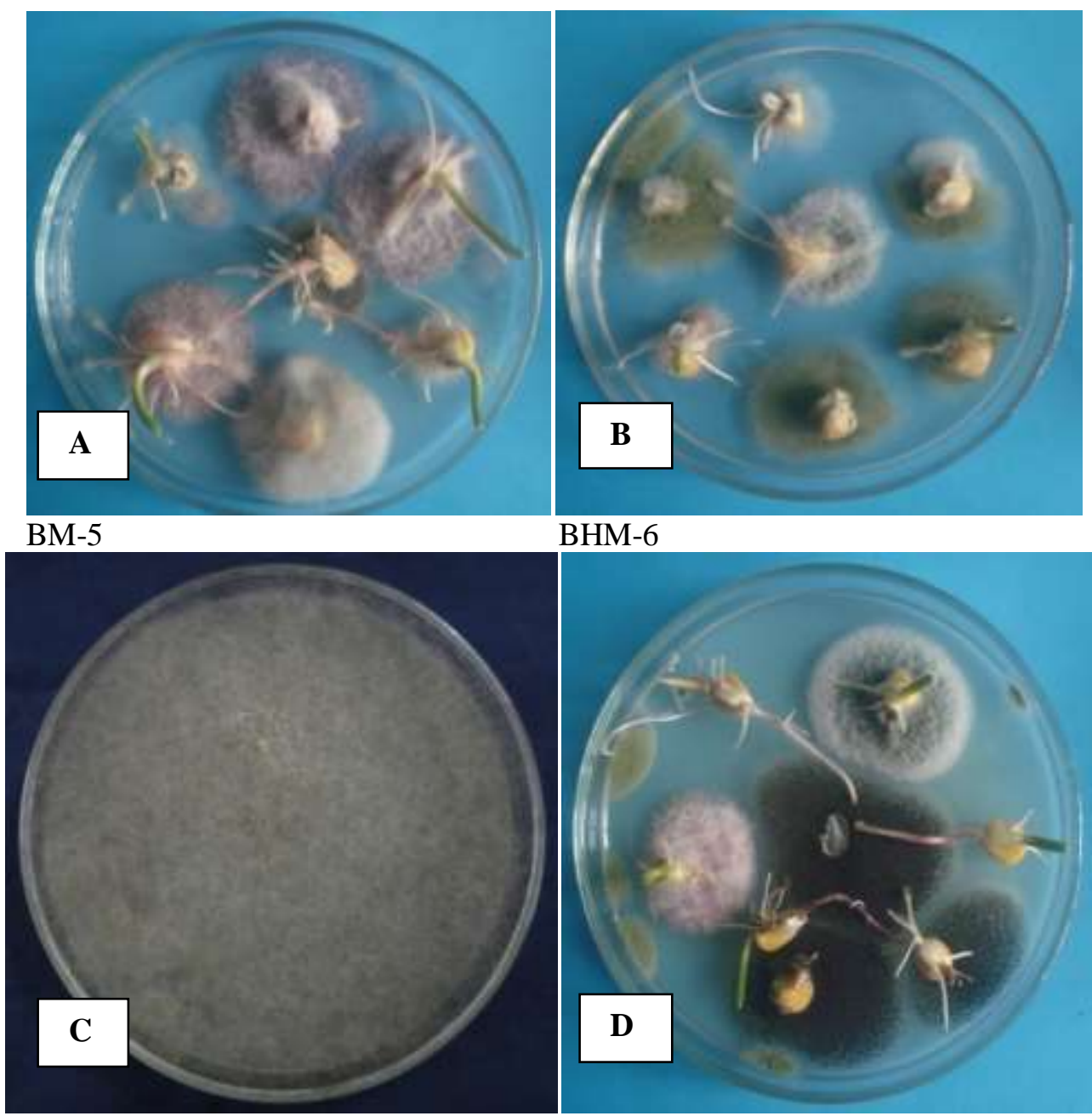

BHM-6
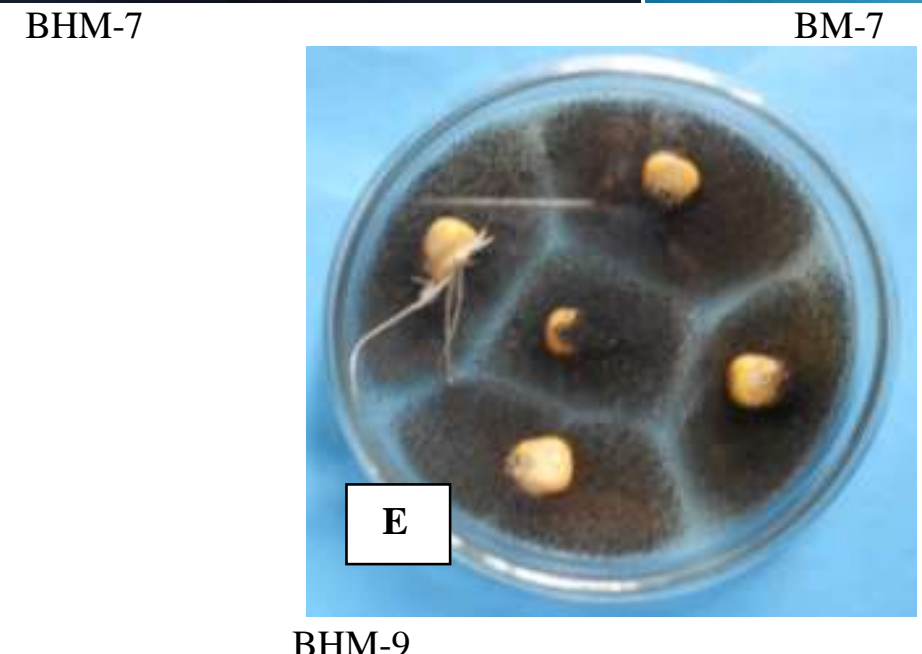

BHM-9

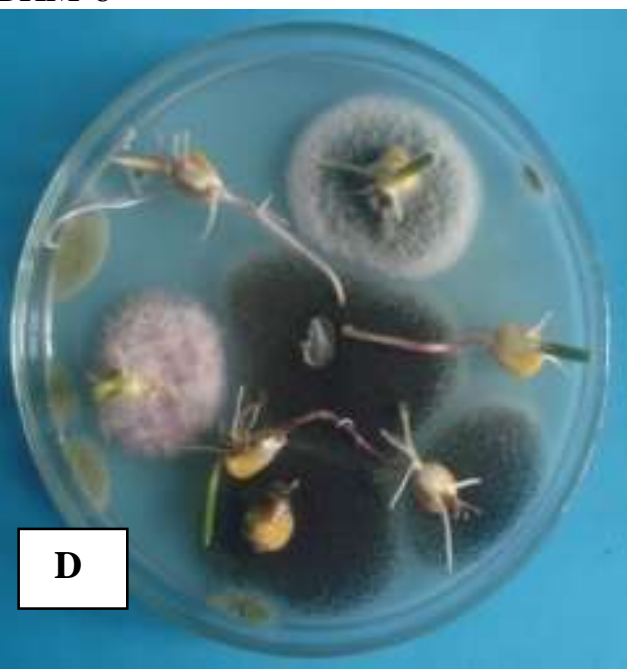

Plate 2. A-E: Fungi associated with different varieties of maize seeds. 